\title{
3D Bioprinters - Future of Implants Biofabrication
}

\author{
Radovan Hudák ${ }^{1 *}$, Jozef Živč́ák ${ }^{2}$, Martin Šarik ${ }^{3}$, Robert Dadej ${ }^{4}$, Richard Raši ${ }^{5}$ \\ 1,2,3,4 Department of Biomedical Engineering and Measurement, Faculty of Mechanical Engineering, Technical University of Košice, Letná 9, \\ 04200 Košice, Slovak Republic \\ ${ }^{5}$ Louis Pasteur University Hospital, Rastislavová 43, 04190 Košice, Slovak Republic
}

\section{BIOGRAPHICAL NOTES}

doc. Ing. Radovan Hudák, PhD. was born in 1976 in Košice, Slovakia. He received his MS and PhD degree in biomedical engineering at Technical University in Košice in 2000 and 2008. Today he is an associative professor and head of prosthetics and orthotics study program and head of Biomedical Engineering Division at the Department of Biomedical Engineering and Measurement, Technical University of Košice. His research interests include additive manufacturing in medicine, medical thermography, industrial thermography, human biomechanics and rehabilitation technologies. From 2004 to 2009 he was a technical assistant at the Center of Refractive Surgery in Kosice. Mr. Hudak has more than 120 publications in home and foreign journals. He is co-author of 3 monographies and 7 books.

Dr.h.c. prof. Ing. Jozef Živčák, PhD. is a professor of biomedical engineering at Technical University in Košice, Slovakia. He was born in 1958. He received his MS and PhD degrees from Technical University in Košice in 1995. Prof. Živčák is from 2009 Doctor Honoris Causa of Uzhorod National University. His research interests include human biomechanics, medical sensorics, medical thermography and rehabilitation technology. Today Mr. Zivcak is head of Department of Biomedical Engineering and Measurement at the Faculty of Mechanical Engineering, Technical University of Kosice. He attended at more than 15 international stays, e.g. at CTU in Prague, Polytechnika Bialystok, Poland, Dresden, Germany, Tokyo, Japan, etc. Since 1998 he is an expert witness in machine and electrical technology member of international committee TC 18 and head of IMEKO in Slovakia - Measurement of Human Functions. Professor Zivcak has more than 200 publications in home and foreign journals. He is an author and coauthor of 8 monographies and 11 books.

Ing. Martin Šarik was born in 1987 in Michalovce, Slovakia. He received his master degree in biomedical engineering at Technical University of Košice in 2011. Today Mr. Šarik is a doctoral student at the Department of Biomedical Engineering and Measurement, Technical University of Košice. His research interests include laser sintering, additive manufacturing, and software thermal analysis. From 2012 he is co-investigator of project Center for research of control of technical, environmental and human risks for permanent development of production and products in mechanical engineering supported by the Research \& Development Operational Programme funded by the ERDF. In 2012/ 2013 he attended the meeting and software training of RadTherm application in Paris, France and Munich, Germany. He is an author and co-author of 3 publications in home and in foreign scientific journal.

Ing. Robert Dadej was born in 1988 in Prešov, Slovakia. He received his MS degree 
in biomedical engineering at Technical University of Košice, at the Department of Biomedical Engineering and Measurements, in 2012. He is since 2012 active as a PhD. student at the Department of Biomedical Engineering and Measurements, at Technical University of Košice. Today he continues his research interests in direct metal laser sintering and additive manufacturing of implants. He is an author and co-author of 2 publications in home and in foreign scientific journal.

MUDr. Richard Raši, PhD., MPH was born in 1971 in Košice, Slovakia. He received his doctor's degree in general medicine at the Pavol Jozef Šafárik University in Košice in 1995. In 1998 he finished his first specialization study in surgery and in 2004 his second degree specialization study in traumatology. He received the MPH - Master of Public Health degree at the Slovak Medical University in Bratislava in 2004 and his PhD degree at the Technical University in Košice in 2010. Today Mr. Raši is a Member of the National Council of the Slovak Republic, Chairman of the Committee of Health of the Slovak National Council and Mayor of the City of Košice. He has been working as a Physician in the Clinic of Traumatology at the University Hospital of Louis Pasteur in Košice since 1995 until now. From 2004 to 2007 he was Vice Director for surgical departments at the University Hospital of L. Pasteur in Košice. From 2007 to 2008 he was Director of the University Hospital in Bratislava. He served as Minister of Health of the Slovak Republic from 2008 to 2010. He participated in internships and medical trainings in Stockholm (Sweden), Worcester (USA), Basel (Switzerland), Reims (France) and in Bratislava (Slovakia).

\section{KEY WORDS}

Additive manufacturing, bioprint, bioprinter, scaffold, organs, tissues.

\section{ABSTRACT}

In a last decade has additive manufacturing passed a long way, where was reached an impressive advance in rapid prototyping technology of fabrication. From plastic and ceramic materials through metals to at the moment most interesting technology of bioprint, where the material which is used for building, directly consist of human tissues. Organ printing, which is based on computer-aided $3 \mathrm{D}$ tissue engineering, offers the wide range for research and development in this area. This article summarizes the present advance in this new and not entirely explored field of bio-additive manufacturing. With the help of this technology can be produced the real 3D models of organs and tissues, that should help surgeons in preoperative planning or can be used like spare "parts" for transplantations. The main emphasis is placed on tissue engineering technology which has the best assumptions to solve transplantation issues. Also this article includes the comparison of devices and materials which are possible to engage within the bio-manufacturing.

\section{Introduction}

The change in the field of biology and bio-engineering has built an background in which the improvements in the life sciences are not only more accessible, but call for the active fellowship of engineering design and fabrication to reach solutions for complex biological problems. This progress, along with the development of new design and fabrication, biomaterials, biology and biomedicine, has advanced the additive manufacturing technology to a broad application in biomedical engineering [1].

Tissue engineering has reached more attention in the past decade, owing to its success in enabling tissue regeneration for therapeutic purposes [2]. Tissue engineering introduces the interdisciplinary area in which are applied the principles of biology and engineering to the evolution of substitutes that repair, improve or restore function of tissue. The main target is to fabricate patient-specific biological substitutes in an attempt to sidestep the restrictions of existing clinical treatments for damaged tissue or organs. The main regenerative tissue engineering approach involves transplantation of cells onto scaffolds [2]. These restrictions include deficiency of donor organs, chronic refusal and cell morbidity. The principal approach includes injection of cells alone, evolution of encapsulated systems and implantations of cells onto scaffolds [2]. The utilization of additive manufacturing (AM) in combination with computer-aided (CA) technologies has offered new possibilities for medical modeling, with using of computer models or additive manufacturing fabricated physical models for representation of patient specific anatomical geometry [1]. 

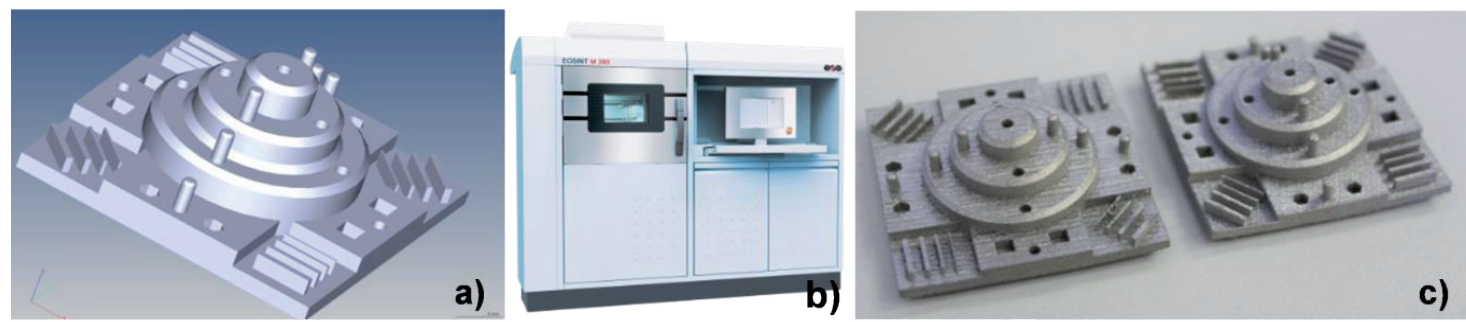

Fig. 1: Example of rapid prototyping fabrication. DMLS method which uses the additive principle to build the real parts. a).STL model of part, b) technology used for manufacture, c) final physical model

\section{Additive Manufacturing \\ A. Rapid Prototyping}

Rapid prototyping also called as solid freeform fabrication and layered (additive) manufacturing technology allow scientist to create physical partsin a short period, directly from 3D models created via computer-aided design (CAD),computer-aided engineering (CAE), and computer-aided manufacturing (CAM) programs as is shown on a Fig. 1 [3, 4, 5]. The additive fabrication refers to a class of manufacturing processes, in which a part is built by adding layers of material upon one another [6]. It offers several advantages as speed, part complexity, wide range of materials to use (plastics, metals, ceramics, composites and even material with properties similar to wood) and low-volume production because there is no need to produce custom tooling. Generally the AM technologies bring the special and unique possibilities for customization, upgrades in product performance, multi-dependence, and lower overall manufacturing costs.

These possibilities include [4]:

\section{- Shape complexity,}

- Material complexity,

\section{- Hierarchical complexity.}

\section{B. Standard 3D printing methods}

Between 3D printing methods which are up to now known, and they differ among themselves by used technology, we classify for example: direct metal laser sintering (DMLS), selective laser sintering (SLS), jetted photopolymer (JP), laminated object manufacturing (LOM), fused deposition modeling (FDM), stereolithography (SLA), three-dimensional printing (3DP) by TheriForm fabrication, precision extruding deposition (PED) and microsyringe based polymer deposition. Several of these methods are used for the bio-additive manufacturing, because they meet the principles and require- ments for printing the living human tissue.

\section{Bio-Additive Manufacturing}

Bio-additive manufacturing (BAM) utilize the principles of standard additive manufacturing to build the physical model which have the same or nearly the same properties like real tissue or organ. BAM should be described as biofabrication using cells, biologics or biomaterials as building blocks to fabricate biological and bio-application oriented substances, devices and therapeutic products through a broad range of engineering, physical, chemical and/or biological processes [1].The research and development (R\&D) of anatomical and biological models represents the most significant area which is necessary for integration of RP in biological engineering. On the Fig. 2 is shown the example procedure of BAM process.

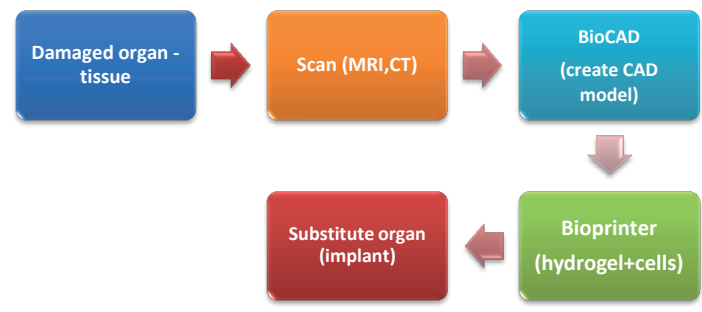

Fig. 2: Example of BAM process which can be modified according to real needs of biofabrication.

Classical tissue engineering refers to seeding isolated cells on solid scaffolds as introduced by Langer and Vacanti almost two decades ago and is still a cutting-edge technology [7].

Biomaterials can offer ideal biocompatible properties for scaffolding and generating cell-scaffold constructs demonstrate promising alternatives for autologous grafting and organ replacement 
[7]. Biofabrication allows cells to be situated in a controlled way in and together with biomaterials. Biofabrication includes various techniques: bioprinting, bioplotting, inkjet printing and stereolithography.

Definition is described as production of complex living and non-living biological products by placing proteins, peptides, DNA, cells, hormones or ECM molecules together with biomaterials [7]. During the BAM process is necessary to ensure fulfillment requirements which are shown on Fig. 3.

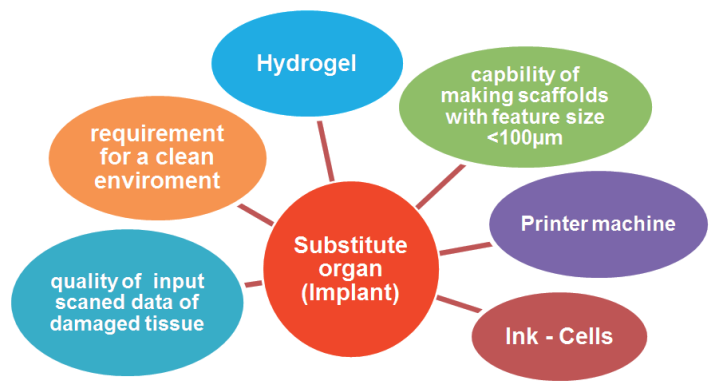

Fig. 3: Requirements for bio-additive manufacturing

As part of the requirements is necessary, to provide taxonomy of communication between scientists from different disciplines (engineering, biology, materials and science) validation of biological tissue for production, biological function and stability of bio-material before and after the manufacture of the product.

\section{A. Rapid Prototyping}

Inkjet 3D printing is a non-contact method which uses digital data from a computer and reproduces it layer-by-layer by putting ink drops on previously printed successive layers [7]. Bioprinters may be constructed in various configurations. However, all bioprinters output cells from a bioprint head that moves in three dimensional (3D) space $(x, y, z)$ in order to place the cells precisely where required. In addition to outputting cells, most bioprinters also output dissolvable water based hydrogel to support and protect cells during printing [10]. Several experimental bioprinters have already been built. The Fig. 4 presents the timeline of bioprinting evolution and its pioneers over the years.

The NovoGen MMX Bioprinter (USA) includes two robotically controlled accuracy print heads: one for placing human cells, the other for placing a hydrogel, scaffold, or support matrix. The NovoGen
(USA) bioprinter is schematically shown on Fig. 5.

One of the most complex challenges in the development of the bio-printer was to perfect a means to consistently position the cell dispensing capillary tip attached to the print head within microns [10]. Invetech (USA) developed a computer-controlled, laser-based calibration system to achieve the required repeatability. The process uses inkjet based 3D printers and an ink made of human cells (as with cloning, using the patient's own cells are the best bet) mixed with a dissolvable gel, often cellulose [10].

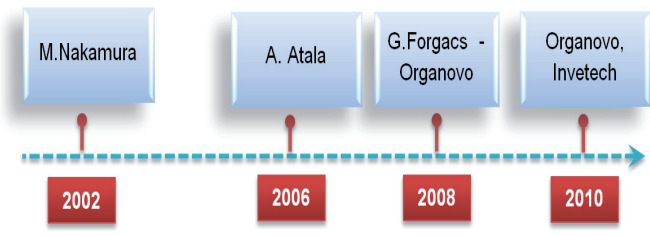

Fig. 4: 2002 - utilization of inkjet principle to bioprint, 2006 - artificial bladder, 2008 - bioprinter NovoGen MMX, 2010 - creation of blood vessels by bioprinter.

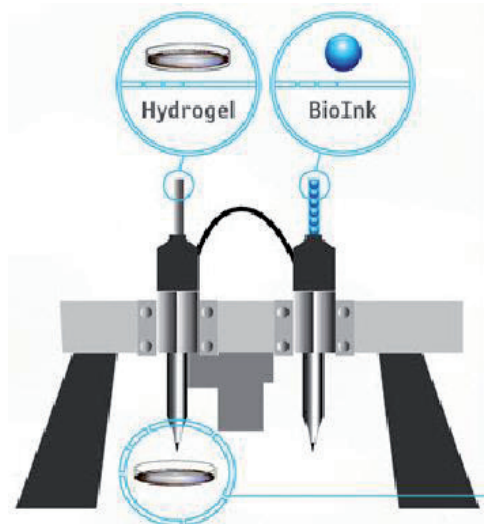

Fig. 5: NovoGen MMX Bioprinter (USA) [15].

The fabrication process is similar to other (AM) techniques. The printer puts down a layer, which is then cured with heat, chemicals or ultra-violet (UV) light, before moving on to the next layer.

To create its output, the NovoGen (USA) first lays down a single layer of a water-based bio-paper made from collagen, gelatin or other hydrogels [12]. Bioink spheroids are then injected into this water-based material. This process is shown on the Fig. 6. After that bioink spheroids slowly fuse together. As this occurs, the bio-paper dissolves away or is removed, than leaving a final bioprinted body part or tissue [10]. 


\section{B. Organ printing}

Organ printing is a biomedically similar variant of RP, which is based on tissue fluidity. Computerassisted deposition (printing) of natural materials (cells or matrix) is done one layer at a time until a particular 3D form is achieved. However, recent attempts using rapid prototyping technologies to design solid synthetic scaffolds receive from the inability to precisely place cells or cell aggregates into a printed scaffold [13]. Organ printing involves three sequential steps: -pre-processing or development, processing or actual organ printing and post processing or organ conditioning [13].
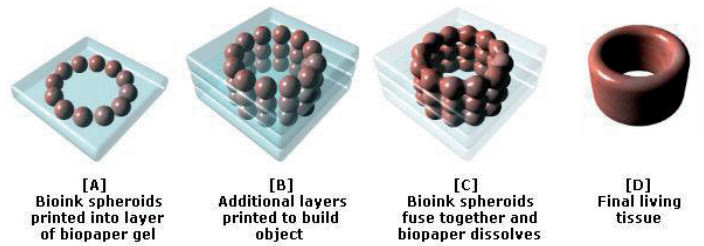

Fig. 6: Principle of bioprint on the cell level [11].

Organ bio-printing applies microfluidic design to cells and cell aggregates starting biological effect such as fusion [10].

\section{Bioplotting}

$3 \mathrm{D}$ bioplotting is a bio-fabrication method, based on the extrusion of continuous filaments. It is sometimes also referred to as direct write system, compared to drop-based deposition in inkjet technology [10].

During the bioplotting, the ink is embedded in a syringe or a similar device and plotted in filaments spatially controlled by an $X, Y$, and $Z$ robotic system.

"One of the first devices for biofunctional and cell compatible printing was developed at the Freiburg Materials Research Center in 2002 under the guidance of Rüdiger Landers and Rolf Mülhaupt and in cooperation with Envision Technologies (Envisiontec GmbH, Gladbeck, Germany)" [7].

\section{Scaffolds}

The scaffold trying's to reproduce the function of the natural extracellular matrix. The primary roles of scaffold are [5]:

I. Serve as an adhesion substrate for the cell, facilitating the localization and delivery of cells when they are implanted.

II. Provide temporary mechanical support to the newly grown tissue by defining and maintaining a

\section{$3 D$ structure.}

III. Guide the development of new tissues with the appropriate function.

Scaffolds can be produced in a variety of ways, using conventional techniques or advanced processing methods.

\section{E. Scaffolds Requirements}

Scaffold produced by bioprinting must fulfill these requirements [5]:

- Fit complex anatomic defects,

- Mechanical strength (e.g., compressive stress 0.5 - $10 \mathrm{MPa}$ ) for temporary load bearing,

- Three dimensional (3D) interconnected macroporous microstructures,

- Controllable biodegradation and bioresorption,

- Suitable surface chemistry,

- Good biocompatibility and biofunctionality.

\section{F. Conventional and Advanced scaffold - fabrication meth-} ods

"Conventional methods for manufacturing scaffolds include solvent casting and particulate leaching, gas foaming, fiber meshes and fiber bonding, phase separation, melt molding, emulsion freeze drying, solution casting and freeze drying" [2]

"Even though these methods have some restrictions which offer: little capability precisely to control pore size, pore geometry, pore interconnectivity, spatial distribution of pores and construction of internal channels within the scaffold" [2].

RP methods such as (FDM), 3D printing (3DP) and (SLS) has been shown to be viable for fabricating porous structures for use in tissue engineering. With use of this advance techniques can be produced the scaffolds which reduce of the restrictions of conventional scaffold fabrication methods as is shown on the Fig. 7.

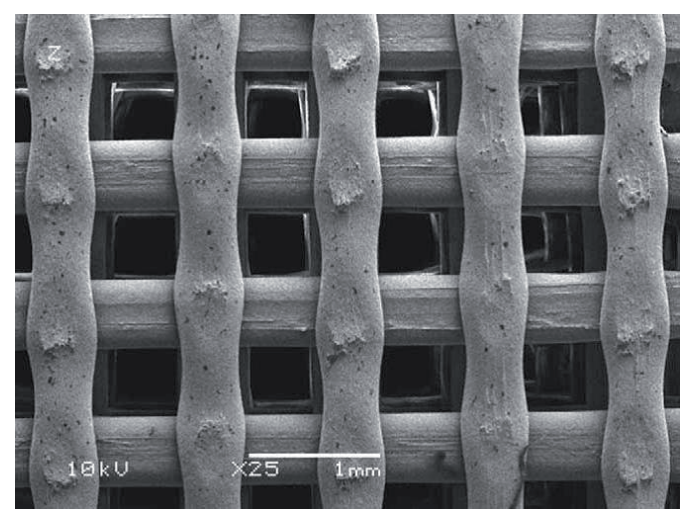

Fig. 7: Structure produced using FDM. 
Table 1: Biofabrication of 3D cell-hydrogel construct [7]

\begin{tabular}{|c|c|c|c|}
\hline Technology & Hydrogel & Cells & Fabrication specifications \\
\hline \multicolumn{4}{|l|}{ Stereolithography } \\
\hline & PEG & Fibroblasts & $\begin{array}{l}\text { Laser beam } \varnothing \sim 250 \mu \mathrm{m} \text {; layer } \\
\text { thickness: } \sim 250 \mu \mathrm{m}\end{array}$ \\
\hline & PEO, PEGDM & Ovary cells & $\begin{array}{l}\text { Ring scaffolds: } \varnothing: 5.3 \mathrm{~mm} \text {; thickness: } \\
1.5 \mathrm{~mm} \text {; UV laser spot: } 250 \mu \mathrm{m} ; \\
\text { resolution per layer: } 150 \mu \mathrm{m} ; \\
\text { x-y resolution: } 250 \mu \mathrm{m}\end{array}$ \\
\hline \multicolumn{4}{|c|}{ Laser-based biofabrication } \\
\hline LGDW & Collagen, Matrigel & ECs, hepatocytes & Single cell resolution \\
\hline BioLP & Matrigel & Osteosacroma cells & $\begin{array}{c}2 \text { layers of cells separated by a } 75 \mu \mathrm{m} \\
\text { layer of hydrogel }\end{array}$ \\
\hline LIFT & $\begin{array}{l}\text { PEGDA, Alginate, } \\
\text { EDTA, blood } \\
\text { plasma, Matrigel; } \\
\text { Collector slide: } \\
\text { agarose }\end{array}$ & $\begin{array}{l}\text { Fibroblasts/keratino } \\
\text { cytes, hMSCs, ECs }\end{array}$ & $\begin{array}{c}\varnothing \text { Droplets: } 80-140 \mu \mathrm{m} \text {; speed: } \\
1200 \text { cell droplets/min; scaffold height } \\
\text { including } 6 \text { layers: } 300 \mu \mathrm{m} \text {; focal spot: } \\
45 \mu \mathrm{m} \text {; distance between spots: } \\
75 \mu \mathrm{m} ; \text { accuracy: } 5 \mu \mathrm{m}\end{array}$ \\
\hline LIFT-2PP & PEGDA & SMCs, ECs & $\begin{array}{c}\varnothing \text { laser spot: } 45 \mu \mathrm{m} \text {; laser transferred } \\
\text { droplet size: } 80-140 \mu \mathrm{m}\end{array}$ \\
\hline \multicolumn{4}{|l|}{ Inkjet printing } \\
\hline \multirow[t]{4}{*}{ Inkjet bioprinter } & $\begin{array}{l}\text { Fibrin gel } \\
\text { (fibrinogen }+ \\
\text { thrombin) }\end{array}$ & Neural cells & $\begin{array}{l}25 \text { orifices with } \varnothing 50 \mu \mathrm{m} \text {, resolution: } \\
85 \mu \mathrm{m} ; 250,000 \mathrm{drops} / \mathrm{s} ; 5 \text { layers }\end{array}$ \\
\hline & $\begin{array}{l}\text { Alginate, } \\
\text { fibrinogen, } \\
\text { thrombin }\end{array}$ & HeLa cells, ECs & $\begin{array}{l}\text { Speed: } 20 \mathrm{~mm} / \mathrm{s} \text {; ejection time: } 800 \\
\mathrm{~Hz} \text {; pattern } \varnothing: 1 \mathrm{~mm} \text {; size: } 5 \times 7 \mathrm{~mm}\end{array}$ \\
\hline & Collagen & SMCs & $\begin{array}{l}\text { Size of construct: } 5 \times 5 \mathrm{~mm}, 5 \text { layers; } \\
\text { thickness per layer: } 16.2 \mu \mathrm{m} ;\end{array}$ \\
\hline & $\begin{array}{l}\text { Fibrin gel } \\
\text { (fibrinogen }+ \\
\text { thrombin) }\end{array}$ & ECs & Size: $10 \times 5 \times 2 \mathrm{~mm} ; 2$ layers \\
\hline \multicolumn{4}{|l|}{$3 D$ bioplotting } \\
\hline Bioplotter & Alginate, Lutrol & BMSCs & $\varnothing$ Nozzle: $100-400 \mu \mathrm{m} ; 4-10$ layers; \\
\hline Envisiontec & $\begin{array}{l}\mathrm{F} 127, \text { Matrigel, } \\
\quad \text { agarose, } \\
\text { methylcellulose }\end{array}$ & BMSCs & $\begin{array}{c}\varnothing \text { Nozzle: } 100-400 \mu \mathrm{m} ; 4-10 \text { layers; } \\
\text { thickness per layer: } 150 \mu \mathrm{m} \text {; spacing } \\
300 \mu \mathrm{m} \text {; speed: } 1-30 \mathrm{~mm} / \mathrm{s} \text {; pressure: } \\
0.5-3 \text { bar; size: } 20 \times 20 \mathrm{~mm}\end{array}$ \\
\hline BAT & $\begin{array}{l}\text { Polyoxyethylene- } \\
\text { polyoxypropylene, } \\
\text { collagen I }\end{array}$ & Fibroblasts, ECs & $\begin{array}{c}\varnothing \text { Nozzle: } 200-500 \mu \mathrm{m} \text {; resolution } \leq 5 \\
\mu \mathrm{m} ; \text { accuracy } \leq 5 \mu \mathrm{m} \text {; deposition rate: } \\
12 \mathrm{~nL} / \mathrm{s}-1 \mathrm{~mL} / \mathrm{s} ; \text { speed: } 10 \mu \mathrm{m} / \mathrm{s}- \\
50 \mathrm{~mm} / \mathrm{s} ; \text { size: } 2 \times 2 \times 1.5 \mathrm{~mm} \text {; layer } \\
\text { height: } 50-100 \mu \mathrm{m} \text {; pressure: } 1.2 \text { bar }\end{array}$ \\
\hline \multirow[t]{3}{*}{ Fab@Home } & Alginate & Chondrocytes & $\begin{array}{c}\varnothing \text { Nozzle: } 840 \mu \mathrm{m} \text {, nozzle precision: } \\
25 \mu \mathrm{m} \text {, width: } 1200 \mu \mathrm{m} \text {; height: } \\
800 \mu \mathrm{m} \text {; flow rate: } 0.6 \mathrm{~mL} / \mathrm{s} \text {; size: } \\
\varnothing: 6 \mathrm{~mm} \times 2 \mathrm{~mm} \text { height }\end{array}$ \\
\hline & Methacrylated & Hepatoma cells, & \\
\hline & $\begin{array}{l}\text { hyaluronic acid, } \\
\text { methacrylated } \\
\text { ethanolamide, PEGs }\end{array}$ & $\begin{array}{l}\text { epithelial cells, } \\
\text { fibroblasts }\end{array}$ & \\
\hline \multirow[t]{2}{*}{ Bioplotter } & Gelatin/chitosan & Hepatocytes & $\begin{array}{c}\varnothing \text { Nozzle: } 300 \mu \mathrm{m} \text {; drop volume: } \\
20 \mathrm{~nL} \text {; lateral resolution: } 10 \mu \mathrm{m} ; \mathrm{X}-\mathrm{Y} \\
\text { velocity: } 10 \mathrm{~mm} / \mathrm{s} \text {; extruding velocity } \\
30 \mathrm{~mm} / \mathrm{min} \text {; pressure: } 0.3 \text { bar; layer } \\
\text { height: } 180 \mu \mathrm{m}\end{array}$ \\
\hline & $\begin{array}{l}\text { Gelatin/ alginate } \\
\text { gelatin/alginate/fibr } \\
\text { inogen } \\
\text { gelatin/alginate/chit } \\
\text { osan }\end{array}$ & $\begin{array}{l}\text { Neuron cells; } \\
\text { Schwann cells, } \\
\text { ADSC, hepatocytes }\end{array}$ & $\begin{array}{l}\varnothing \text { Nozzle: } 250 \mu \mathrm{m}, \mathrm{X}-\mathrm{Y} \text { velocity: } \\
5 \mathrm{~mm} / \mathrm{s} \text {; extruding velocity } 15 \\
\mathrm{~mm} / \mathrm{min} \text {; layer height: } 150 \mu \mathrm{m} ; \\
\text { width: } 380 \mu \mathrm{m}\end{array}$ \\
\hline $\begin{array}{l}\text { Multi-nozzle SFF } \\
\text { deposition system }\end{array}$ & Alginate & $\begin{array}{l}\text { ECs, fibroblasts, } \\
\text { hepatocytes }\end{array}$ & $\begin{array}{c}\text { Droplet-based or continuous } \\
\text { deposition; } \varnothing \text { Nozzle: } 30-500 \mu \mathrm{m} ; \\
\text { velocity: } 10 \mathrm{~mm} / \mathrm{s} ; \text { pressure: } 0.3-2.8 \text { bar; } 40 \\
\text { layers }\end{array}$ \\
\hline $\begin{array}{l}\text { Cell writing } \\
\text { system }\end{array}$ & $\begin{array}{l}\text { Alginate with iron } \\
\text { oxide nanoparticles }\end{array}$ & ECs & $\begin{array}{l}\text { Size of construct: } 5 \times 5 \times 2 \mathrm{~mm} \\
\text { Printing pressure: } 0.3 \mathrm{bar}\end{array}$ \\
\hline $\begin{array}{l}\text { Dispensing-based } \\
\text { deposition system }\end{array}$ & $\begin{array}{c}\text { Mebiol } \\
\text { (Nisopropylamid } \\
\text { and } \\
\text { polyoxyethylene) }\end{array}$ & Insect cells & $\begin{array}{c}\text { Feed speed: } 0.5-0.83 \mathrm{~mm} / \mathrm{s} \text {; pressure: } \\
0.3-0.4 \text { bar; line width: } \\
114-300 \mu \mathrm{m} \text {; size: } 1 \times 1 \mathrm{~mm}\end{array}$ \\
\hline nScrypt bioprinter & Collagen I, agarose & $\begin{array}{l}\text { Embryonic cardiac } \\
\text { cells, ECs, ovary } \\
\text { cells, SMCs, } \\
\text { fibroblasts }\end{array}$ & $\begin{array}{c}\text { Tubes: } \varnothing 900-25,000 \mu \mathrm{m} \text {, wall } \\
\text { thickness } 300 \mu \mathrm{m}\end{array}$ \\
\hline
\end{tabular}

a (LGDW = Laser-Guided Direct Writing; BioLP = Biological Laser Printing; LIFT = Laser Induced Forward Transfer; $2 P P=$ Two-Photon Polymerization; BAT = BioAssembly Tool; ECs = endothelial cells; hMSCs = human mesenchymal stem cells; SMCs = smooth muscle cells; BMSCs = bone marrow stromal cells; $A D S C s=$ adipose-derived stromal cells; $P E G=$ poly (ethylene glycol); $D M=$ dimethacrylate; $D A=$ diacrylate). 


\section{Comparison Between the Different Biofabrica- tion Techniques}

Table 1 shows the comparison among various bioprinting technologies, which uses the different scaffold materials and cells, which leads to differences in a final accuracy of printed models. [7]

\section{Conclusion}

In the last decade has been presented many investigations of new techniques for biofabricating of 3D cellular constructs using complex designs. The amount of research and the creation of new companies indicate the strong growth potential of this new field. 3D biofabrication can be appropriate for the production of required, shape complex scaffold geometries with different materials. It further has the potential to offer a controlled placement of viable cells. Organ printing is currently viable, fast evolving and predicted to be a major technology in tissue engineering. Scaffolds are very important for the fabrication of functional living implants out of cells obtained from cell culture. The scaffold materials should be nonantigenic, nontoxic, and nonteratogenic and possess high cell/tissue biocompatibility so that they will not trigger pathological reactions after implantation.

Requirements of scaffolds are: individual external shape and well defined internal structure with interconnected porosity to host most cell types [5]. In time span of several years, it is expected that 3D bioprinting will be at a level when it will be possible to create complex organs such as kidneys, liver, heart etc. These organs than could be used, apart from the substitutes as educational tool for the study of medicine, for the preparation before major surgery or in the pharmaceutical industry for drug testing without the need for continued use of animals. In the nearest future, it is necessary to solve a number of problems related to bio-additive manufacturing, is there particularly the development of new materials, optimal design of substitutes of associated parts of the human body with the knowledge of physiology of cells, including optimum betting action of cells and vascularization.

\section{Acknowledge}

Presented paper was supported by project Research of New Diagnostic Methods in Invasive Implantology, MŠSR-3625/2010-11, Stimuls for Research and Development of Ministry of Education, Science, Re- search and Sport of the Slovak Republic.

\section{References}

[1] Bourell, D. L., Leu, M. C., Rosen, D. W. (2009). Roadmap for Additive Manufacturing, Identifying the Future of Freeform Processing, University of Texas.

[2] Yeong, W. Y., Chua, Ch. K., Leong, K. F. and Chandrasekaran, M. (2004). Rapid prototyping in tissue engineering: challenges and potential, TRENDS in Biotechnology Vol.22 No.12 December.

[3] Lantada, A. D., Morgado, L. P., (2012). Rapid prototyping for biomedical engineering: current capabilities and challenges, Annu. Rev. Biomed. Eng

[4] Rosen, D. W. Design For Additive Manufacturing: A Method To Explore Unexplored Regions Of The Design Space, The George W. Woodruff School of Mechanical Engineering, Georgia Institute of Technology.

[5] Jun, M. B. G. (2009). Rapid prototyping, solid free form fabrication and additive manufacturing, Mechanical Engineering, University of Victoria.

[6] Additive fabrication, [Cited on 2013-03-10], available at: <http://www.custompartnet.com/wu/additive-fabrication>

[7] Wüst, S., Müller, R. and Hofmann, S. (2011). Controlled Positioning of Cells in Biomaterials-Approaches Towards 3D Tissue Printing, Journal of Functional Biomaterials ISSN 2079-4983.

[8] Bioprinter. [Cited on 2013-03-10], available at: <http://forgacslab.missouri.edu/bioprinter.html>

[9] A review of trends and limitations in hydrogel-rapid prototyping for tissue engineering. [Cited on 2013-03-10], available at: <http://www.sciencedirect.com/science/article/ pii/S0142961212004899>

[10] Mironov, V., Boland, T., Trusk, T., Forgacs, G. and Markwald, R. R. (2003). Organ printing: computer-aided jet-based 3D tissue engineering, TRENDS in Biotechnology Vol.21 No.4 April.

[11] Kim, G. H., Son, J. G. (2008). 3D polycarprolactone (PCL) scaffold with hierarchical structure fabricated by a piezoelectric transducer (PZT)-assisted bioplotter, Applied Physics A, Springer-Verlag

[12] HOLLISTER, S. J. (2005). Porous scaffold design for tissue engineering, Nature Publishing Group.

[13] Murphy, V.S., Skardal, A., Atala, A. (2012). Evaluation of hydrogels for bio-printing applications, Society for Biomaterials, published online 31. August.

[14] Injectable and thermosensitive PLGA-g-PEG hydrogels containing hydroxyapatite: preparation, characterization and in vitro release behavior. [Cited on 2013-03-10], available at: <http://www.ncbi.nlm.nih.gov/pubmed/22456931> 
Acta Mechanica Slovaca

Journal published by Faculty of Mechanical Engineering - Technical University of Košice

[15] Bioprinting. [Cited on 2013-03-10], available at: <http:// www.explainingthefuture.com/bioprinting.html >

[16] The Amazing History and Future of Bioprinting. [Cited on 2013-03-10], available at: <http://www.webpronews.com/ the-amazing-history-and-future-of-bioprinting-infographic-2012-07>

[17] Traction Stresses and Translational Distortion of the Nucleus during Fibroblast Migration on a Physiologically Relevant ECM Mimic. [Cited on 2013-03-10], available at: <http://www.sciencedirect.com/science/article/pii/ S0006349509006018\#>

[18] Tsang, V. L., Chen, A. A, Cho, L.M., Jadin, K. D., Sah, R. L., et al. (2007). Fabrication of 3D hepatic tissues by additive photopatterning of cellular hydrogels, The FASEB Journal vol. 21 no. 3, March.

[19] Fedorovich, N. E., Alblas, J., Henning, W. E., Öner, F. C. and Dhert, W. J. A. (2011). Organ printing: the future of bone regeneration?, Trends in Biotechnology, Vol. 29, No. 12, December.

[20] Moroni, L., Wijn, de J., Blitterswijk, van C. A. (2004). 3D Plotted Scaffolds for Tissue Engineering: Dynamical Mechanical Analysis, European Cells and Materials Vol. 7. Suppl. 1.

[21] Vozda, M., Sekora, M., Penhaker, M. " Precise Temperature Stabilizing System of Liquids for the Purpose Biomedical Applications" In Journal Electronics and Electrical Engineering, vol.18, Iss 10., pp. 29 - 32, Received 3rd MArch 2012, Accepted 12th May 2012; Published October 2012. ISSN 1392 - 1215 (print), ISSN 2029-5731 (online)

[22] Sidun, J., Dabrowski, J.R.: Bone Ingrowth Processes on Porous Metalic Implants, 2009, Solid State Phenomena, 147149, 776 <http://www.scientific.net/SSP.147-149.776> 